\title{
Up-regulation of hypoxia inducible factor- $1 \alpha$ by cobalt chloride correlates with proliferation and apoptosis in PC-2 cells
}

\author{
Zhi-Jun Dai ${ }^{1 * \dagger}$, Jie Gao ${ }^{2 \dagger}$, Xiao-Bin Ma ${ }^{1}$, Kun Yan ${ }^{3}$, Xiao-Xu Liu', Hua-Feng Kang ${ }^{1}$, Zong-Zheng Ji ${ }^{3}$, Hai-Tao Guan ${ }^{1}$ \\ and Xi-Jing Wang ${ }^{1 *}$
}

\begin{abstract}
Background: The exact mechanism of the effects of hypoxia on the proliferation and apoptosis in carcinoma cells is still conflicting. This study investigated the variation of hypoxia-inducible factor- $1 \alpha(\mathrm{HIF}-1 \alpha)$ expression and the apoptosis effect of hypoxia stimulated by cobalt chloride $\left(\mathrm{CoCl}_{2}\right)$ in pancreatic cancer PC-2 cells.

Methods: PC-2 cells were cultured with different concentration (50-200 $\mu \mathrm{mol} / \mathrm{L}$ ) of $\mathrm{CoCl}_{2}$ after 24-120 hours to simulate hypoxia in vitro. The proliferation of PC-2 cells was examined by MTT assay. The cellular morphology of PC-2 cells were observed by light inverted microscope and transmission electron microscope(EM). The expression of HIF-1 $\alpha$ on mRNA and protein level was measured by semi-quantitive RT-PCR and Western blot analysis. Apoptosis of PC-2 cells were demonstrated by flow cytometry with Annexin V-FITC/PI double staining.

Results: MTT assay showed that the proliferation of PC-2 cells were stimulated in the first $72 \mathrm{~h}$, while after treated over $72 \mathrm{~h}$, a dose- dependent inhibition of cell growth could be observed. By using transmission electron microscope, swollen chondrosomes, accumulated chromatin under the nuclear membrane and apoptosis bodies were observed. Flow cytometer(FCM) analysis showed the apoptosis rate was correlated with the dosage of $\mathrm{CoCl}_{2}$. RT-PCR and Western blot analysis indicated that hypoxia could up-regulate the expression of HIF-1 $1 \alpha$ on both mRNA and protein levels.
\end{abstract}

Conclusion: Hypoxic microenvironment stimulated by $\mathrm{CoCl}_{2}$ could effectively induce apoptosis and influence cell proliferation in PC-2 cells, the mechanism could be related to up-expression of HIF-1 $\alpha$.

Keywords: Pancreatic carcinoma, Hypoxia, Cobalt chloride, HIF-1 $\alpha$ ?a?, Apoptosis, Proliferation

\section{Background}

Hypoxia is one of the most important pathological characteristics of solid tumor which is the result of imbalance between tumor cell proliferation and blood supply [1]. As solid tumor growing, its center becomes a hypoxic area because of lacking blood and oxygen. The hypoxic status of various solid tumor has been recognized as an important determinant for the outcome of anti-cancer therapies in a number of tumors [2].

\footnotetext{
* Correspondence: dzj0911@126.com; Wangxijing@21cn.com

+ Contributed equally

'Department of Oncology, the Second Affiliated Hospital, Medical School of Xi'an Jiaotong University, Xi'an, China

Full list of author information is available at the end of the article
}

Hypoxia-inducible factor-1 (HIF-1) was found in the 1992 when Semenza [3] researched the expression of erythropoietin gene induced by hypoxia. Human HIF-1 has been depurated and isolated, it is a heterodimeric transcription factor composed of oxygen-dependent HIF- $1 \alpha$ and constitutively expressed HIF- $1 \beta$ subunits, HIF-1 transcriptional activity is largely determined by regulated expression of the HIF-1 $\alpha$ subunit [4]. HIF- $1 \alpha$ over-expression has been detected in various tumors including breast, oropharyngeal, nasopharyngeal, prostate, brain, lung, stomach cancer and so on, and has been associated with tumor aggressiveness, vascularity, treatment failure and mortality [5-7]. Interestingly, HIF$1 \alpha$ can also over-expressed under normoxic conditions in some human tumors [8].

\section{C) Biomed Central}


In this research, we treated a human pancreatic cancer cell line $(\mathrm{PC}-2)$ with cobalt chloride $\left(\mathrm{CoCl}_{2}\right)$ to stimulate hypoxia in vitro. Under the hypoxic condition, we observed the proliferation of PC-2 cells by MTT assay. Meanwhile, RT-PCR and Western blot analysis were conducted to measure the expression of HIF-1 $\alpha$ on mRNA and protein level. Furthermore, we discussed the effect of hypoxic microenvironment on apoptosis and its mechanism.

\section{Materials and methods Reagents}

Fetal bovine serum (Gibco, USA); RPMI1640 medium (Gibco, USA); 3-(4,5) -dimethylthiahiazo(-z-y1)-3,5diphenyte- trazoliumromide (MTT) (Gibco, USA); annexin V-FITC/PI apoptosis detection kit (Becon Dickinson Facsalibur, USA); RT-PCR kit (ampliqon, Denmark); Trizol (Invitrogen, USA); HIF-1 $\alpha$ monoclonal antibody (Santa Cruz Biotechnology, USA); 3-(5'-hydroxymethyl-2'-furyl)-1 -benzylindazole (YC-1) (Shanghai Shenggong Biological Engineering Technology\&Service, China); $\mathrm{CoCl}_{2}$ (Shanghai Shenggong Biological Engineering Technology\&Service, China).

\section{Cell line and cell culture}

Human pancreatic cancer cell line, PC-2, was purchased from the medical experimental animal center of the fourth military medical university. Cells were cultured in RPMI 1640 maximal medium containing 10\% inactived fetal bovine serum $\left(56^{\circ} \mathrm{C}, 30 \mathrm{~min}\right), 1 \times 10^{5} \mathrm{U} / \mathrm{L}$ penicillin and $100 \mathrm{mg} / \mathrm{L}$ streptomycin in a humidified atmosphere with $5 \% \mathrm{CO}_{2}$ incubator at $37^{\circ} \mathrm{C}$.

\section{MTT assay for the proliferation of PC-2 cells}

The proliferation of PC-2 cells was assessed using MTT dye reduction assay (Sigma, USA), which was conducted as described previously [9]. PC-2 cells were seeded in a 96well plate at a density of $1 \times 10^{4}$ cells/well, cultured for 12 $\mathrm{h}$ under $37^{\circ} \mathrm{C}$ in $5 \% \mathrm{CO}_{2}$, then treated with different concentration $(50,100,150,200 \mu \mathrm{mol} / \mathrm{L}) \mathrm{CoCl}_{2}$ for 24-120 h. At the end of the treatment, MTT, $50 \mu \mathrm{g} / 10 \mu \mathrm{L}$, was added and the cells were incubated for another 4 hours. Dimethylsufloxide (DMSO; $200 \mu \mathrm{l}$ ) was added to each well after removal of the supernatant. After shaking the plate for 10 min, cell viability was assessed by measuring the absorbance at $490 \mathrm{~nm}$ using an Enzyme-labeling instrument (EX-800 type); all measurements were performed three times. Cell growth curve was completed using time as the abscissa and $A$ value (mean $\pm \mathrm{SD}$ ) as the ordinate.

\section{Detection of morphological change by transmission electron microscope}

Uranyl acetate and lead citrate staining of cells were performed to detect morphological changes. Briefly, adherent PC-2 cells were treated with $200 \mu \mathrm{mol} / \mathrm{L}$ $\mathrm{CoCl}_{2}$ for 48 hours. After treatment, the treated cells were digested with pancreatin and fixed with $3 \%$ glutaraldehyde precooled in $4^{\circ} \mathrm{C}$ for 2 hours. To make ultrathin sections of copper, cells were washed with phoisphate-buffered salein (PBS) once, fixed with $1 \%$ osmic acid for 1 hour, dehydrated by acetone and embedded in epoxide resin. After staining with uranyl acetate and lead citrate, the sections were examined by a Hitachi800 transmission electron microscope [10].

\section{Semi-quantitative reverse transcription polymerase chain reaction (RT-PCR) assay}

PC-2 cells were seeded in $6 \mathrm{~cm}$ culture capsules and treated with concentration gradient $\mathrm{CoCl}_{2}(0,50,100$, $150,200 \mu \mathrm{mol} / \mathrm{L})$ separately for $8 \mathrm{~h}$. In the group of 200 $\mu \mathrm{mol} / \mathrm{L}$, we selected cells at $0 \mathrm{~h}, 4 \mathrm{~h}, 8 \mathrm{~h}$ and $12 \mathrm{~h}$ point for further experiment. And then treated with $2.0 \mu \mathrm{mol} /$ L YC-1 $(0,50,100,150$,) for 2 h. As previously described [11], cells collected at specified time were used to extract total RNA using the Trizol reagent following the manufacturer's instructions. $1 \mu \mathrm{gRNA}$ synthetized cDNA through reverse transcriptase undergo listed below condition: $70^{\circ} \mathrm{C} 5 \mathrm{~min}, 42^{\circ} \mathrm{C}$ extended for $60 \mathrm{~min}, 95^{\circ} \mathrm{C}$ enzyme inactivated for $3 \mathrm{~min}$ and $4^{\circ} \mathrm{C}$ terminated reaction. Synthetical cDNA as template to carry out polymerase chain reaction. HIF- $1 \alpha$ primer sequence (Invitrogen CO): 5'-ACTTCTGGATGCTGGTGATT-3' (sense) and 5'TCCTCGGCTAGTTAG GGTAC -3' (anti-sense), amplification fragment was $325 \mathrm{bp}$, renaturation temperature was $55^{\circ} \mathrm{C}$ (cycling 35 times). $\beta$-actin, its primer sequence was 5'-GTTGCGTTACACCCTTTCTTG-3' (sense), 5'-TGCTGTCACCTTCACCGT TC-3' (antisense), amplification fragment was $133 \mathrm{bp}$, and renaturation temperature was $55^{\circ} \mathrm{C}$ (cycling 40 times). Amplification condition was below: pre-denaturized for $3 \mathrm{~min}$ at $95^{\circ} \mathrm{C}$, denaturized for $30 \mathrm{~s}$ at $95^{\circ} \mathrm{C}$, renaturated for $30 \mathrm{~s}$ at $55^{\circ} \mathrm{C}$ and extended for $30 \mathrm{~s}$ at $72^{\circ} \mathrm{C}$. PCR product was detected on agarose gel electrophoresis and ethidium bromide imaging system was used to make density index analysis. The expression intensity of HIF-1 $\alpha$ mRNA was denoted with the ratio of the photodensity of the RT-PCR products of HIF- $1 \alpha$ and $\beta$-actin.

\section{Western blot analysis}

As previously described [12], cells were washed with icecold PBS twice and lysed with lysis buffer containing 1\% NP40, $137 \mathrm{mM} \mathrm{NaCL}, 20 \mathrm{mM}$ Tris base(pH7.4), $1 \mathrm{mM}$ DTT, $10 \%$ glycerol, $10 \mathrm{mg} / \mathrm{mL}$ Aprotinin, $2 \mathrm{mM}$ sodium vanadate and $100 \mu \mathrm{M}$ PMSF. Protein concentrations were determined using the PIERCE BCA protein assay kit. Protein was separated by $10 \%$ SDS-PAGE under denaturing conditions and transferred to nitrocellulose 
membranes. Membranes were incubated with an mouse HIF-1 $\alpha$ monoclonal antibody (1:1000; Santa Cruz Biotechnology), followed by incubation in goat antimouse secondary antibody conjugated with horseradish peroxidase (1:1000; Santa Cruz Biotechnology). Immunoreactive proteins were visualized using enhanced chemiluminescence detection system (Amersham Biosciences)

\section{Apoptosis detection by FCM}

Apoptotic cells were differentiated from viable or necrotic ones by combined application of annexin V-FITC and propidium iodide (PI) (BD Biosciences Clontech, USA) [13]. The samples were washed twice and adjusted to a concentration of $1 \times 10^{6}$ cells $/ \mathrm{mL}$ with $4^{\circ} \mathrm{C}$ PBS. The Falcon tubes $(12 \mathrm{~mm} \times 75 \mathrm{~mm}$, polystyrene round-bottom) were used in this experiment, $100 \mu \mathrm{L}$ of suspensions was added to each labeled tube, $10 \mu \mathrm{L}$ of annexin V-FITC and $10 \mu \mathrm{L} \mathrm{PI}(20 \mu \mathrm{g} / \mathrm{mL})$ were added into the labeled tube, incubated for at least $20 \mathrm{~min}$ at room temperature in the dark, then $400 \mu \mathrm{L}$ of PBS binding buffer was added to each tube without washing and analyzed using FCM analysis (BD Biosciences Clontech, USA) as soon as possible (within $30 \mathrm{~min}$ ). This assay was done quintuplicate.

\section{Statistical analysis}

All data were expressed by mean \pm S.E.M. Statistical analyses were performed using SPSS 11.0 for Windows software. ANOVA (one-way analysis of variance) and Student's $t$-test were used to analyze statistical differences between groups under different conditions. $P$ value $<0.05$ was considered statistically significant.

\section{Results}

\section{The influence of hypoxia on PC-2 cells proliferation}

We studied the proliferation of PC-2 cells under hypoxia simulated by $\mathrm{CoCl} 2$ using MTT assay. As shown in Figure 1 , the growth curve of cells under normoxia showed "S" shape: 24-48 h was detention period (slowly grow), 72-96 h were exponential phase of growth (rapidly proliferate), the following $24 \mathrm{~h}$ was platform period. Compared with the normoxic group, the cells of hypoxic group didn't show "S" shape. Following a 72 h hypoxic exposure, the proliferation speed of cells under hypoxia was faster, $72 \mathrm{~h}$ later, the speed was slower, achieved saturation density in advanced, went into platform period but gradually degraded at 96-120 h. Meanwhile, as the hypoxia became serious, this phenomenon was more conspicuous. After treated over $72 \mathrm{~h}$, a dose- dependent inhibition of cell growth could be observed.

Morphological changes of PC-2 cells induced by hypoxia By using transmission electron microscope, normal PC-2 cells were round and regular, with abundant organelles, the chromatin margination showed in few cells (Figure 2A). After treated with $\mathrm{CoCl}_{2}$ for 48 hours, part of nuclear membrane domed outward with a sharp angle. The following different apoptotic periods could be observed. (1) Early stage of apoptosis: the nuclei showed chromatin pyknosis, and were clustered on the inner border of karyotheca; cytoplasm condensation and swelling of mitochondria were observed in the inner segment; the nucleus was at one end of the cell with complete karyotheca and many mitochondria in the cytoplasm showed the early ultrastructure changes of apoptosis (Figure 2B). (2) Middle stage of apoptosis: in addition to the swelling of mitochondria and many vacuoles, the surface of cellular membrane process to crassitude, and the endoplasmic reticulum was abundant; the typical changes were karyopyknosis or karyorrhexis (Figure 2C). (3) Late stage of apoptosis: characterized by changes such as shrinkage, condensation of nuclear chromatin, fragmentation of nuclei and formation of apoptotic bodies (showed in Figure 2D)

\section{Expression of HIF- $1 \alpha$ mRNA detected by semi-quantitive RT-PCR}

RT-PCR revealed HIF- $1 \alpha$ mRNA expressed rarely in normoxic PC-2 cells, as $\mathrm{CoCl}_{2}$ density increased its expression gradually increased (Figure $3 \mathrm{~A}$ ). When cells treated with $200 \mu \mathrm{mol} / \mathrm{L} \mathrm{CoCl}_{2}$, accompanied with the action time extended the expression of HIF-1 $\alpha$ mRNA increased (Figure 3B). The correlation of $\mathrm{CoCl}_{2}$ and HIF- $1 \alpha$ mRNA was a dose- and time-dependent manner. After treated with $\mathrm{YC}-1$ for $2 \mathrm{~h}$, overexpression of HIF- $1 \alpha$ mRNA induced by $\mathrm{CoCl}_{2}$ was significantly down-regulated (Figure 3B).

\section{Expression of HIF-1 $\alpha$ protein detected by western blot analysis}

The protein level of HIF-1 $\alpha$ was measured in PC-2 cells treated with different doses of $\mathrm{CoCl}_{2}$ by Western blot analysis employing mouse monoclonal HIF-1 $\alpha$ antibodies. As shown in Figure 3C, the amount of HIF-1 $\alpha$ protein after $\mathrm{CoCl}_{2}$ treatment was significantly increased in a dose-dependent manner $(P<0.05)$. These data demonstrated that hypoxic microenvironment simulanted by $\mathrm{CoCl}_{2}$ could up-regulate HIF-1 $\alpha$ expression.

\section{FCM analysis of cell apoptosis induced by hypoxia}

After treatment with different doses of $\mathrm{CoCl}_{2}$ for $72 \mathrm{~h}$, apoptosis induction was demonstrated using FCM analysis. Apoptotic cells were differentiated from viable or necrotic ones by combined application of annexin $\mathrm{V}$ FITC and PI. Apoptotic and necrotic cells were distinguished according to annexin V-FITC reactivity and PI exclusion. As shown in Figure 4, in normoxic group, there were almost normal cells, rarely viable apoptotic 


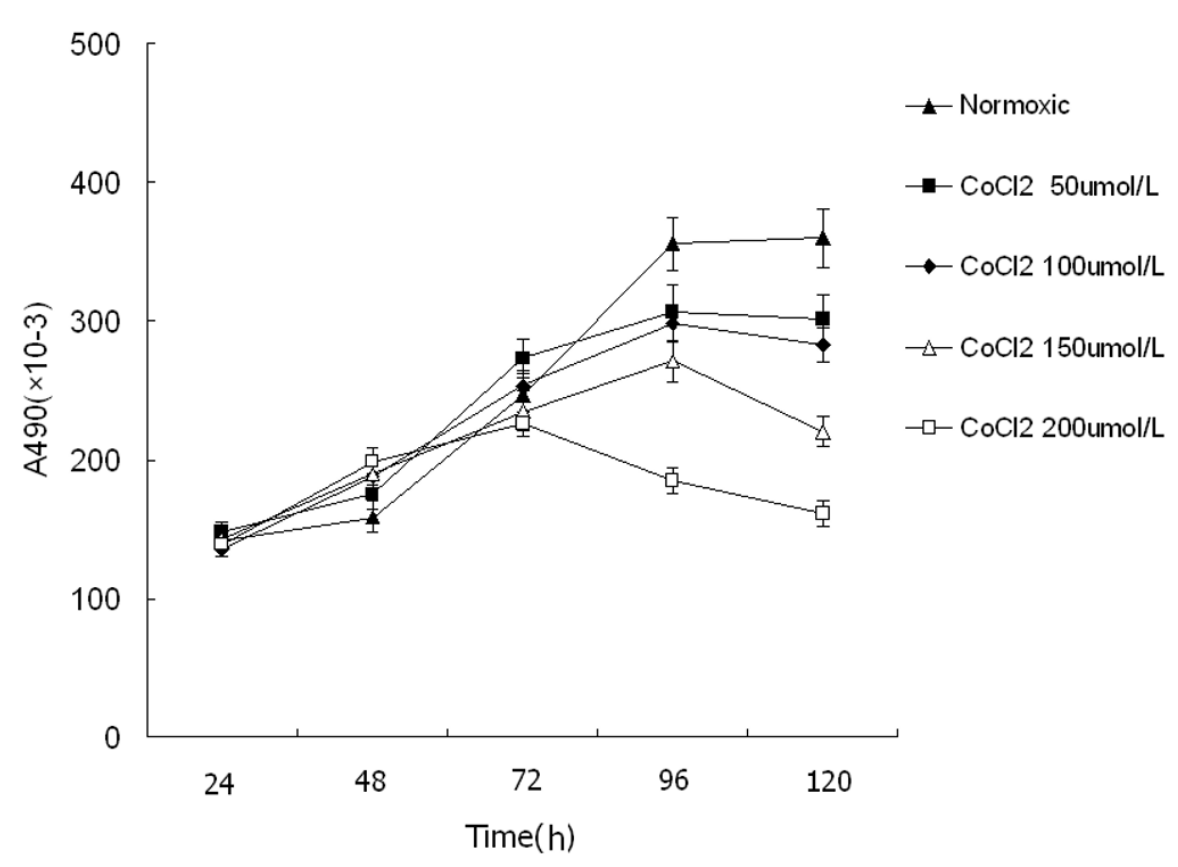

Figure 1 The growth curve of PC-2 cells treated with different dose of $\mathrm{CoCl}_{2}$. Cell viability was determined by MTT method. This assay was performed in triplicate. Dose- dependent inhibition of cell growth could be observed after $72 \mathrm{~h}(P<0.05$, ANOVA analysis).

cells; while in hypoxic group, the rate of apoptotic cells was gradually increased along with increasing concentrations of $\mathrm{CoCl}_{2}$. The rate of apoptosis in normoxic, 100$200 \mu \mathrm{mol} / \mathrm{L} \mathrm{CoCl} 2$ group were $10.77 \%, 34.32 \%, 40.17 \%$, $52.30 \%$, respectively. Furthermore, apoptotic cells gradually increased in a dose-dependent manner.

\section{Discussion}

More recently, experimental and clinical studies demonstrated that intra-tumor hypoxia might be a key factor in tumor microenvironment promoting invasive growth and metastasis [14]. The increased malignancy of hypoxic tumors has been attributed to the ability of hypoxia to select for cells with diminished apoptotic potential and to induce their clonally expansion [15]. Since the hypoxic phenomenon in tumors was revealed, more and more evidence indicated hypoxia existed in solid tumor generally [16].

Pancreatic cancer is common malignant tumor of digestive system which has high malignancy, difficulty in treatment and poor prognosis. And less than $10 \%$ of pancreatic cancer is resectable when being diagnosised and 5-year overall survival rate is less than 5\% [17]. During the development of pancreatic cancer, the blood can't supply the tumor nourishment, thus the tumor are hypoxic partly, while hypoxia makes the tumor cell more malignant. In this way, the rapid growth and the hypoxia are unity of opposites in tumors [18].
$\mathrm{CoCl}_{2}$ is a chelator which instead of $\mathrm{Fe}^{2+}$ in hemoglobin, and then damage cell's reception of oxygen [19]. The mechanism of $\mathrm{CoCl}_{2}$ simulating hypoxia is similar with hypoxic microenvironment in vivo, because they have identical signal transduction and transcription regulation. Moreover previous research demonstrated $\mathrm{CoCl}_{2}$ correlated with proliferation and apoptosis in human carcinoma cells $[20,21]$. In our study, we treated PC-2 cells with $\mathrm{CoCl}_{2}$ to simulate hypoxic microenvironment, MTT assay revealed along with the increased $\mathrm{CoCl}_{2}$ concentration, the exponential phase of PC-2 cells was earlier in advanced and persisted shorter, cells grew slower and went into platform period early(Figure 1). It is reasonable to assume that the step down in PC2 cell proliferation correlated with the increased hypoxia, hypoxic microenvironment could slow down the speed of tumor growth.

HIF-1 $\alpha$, a transcription factor regulating genes' expression induced by hypoxia, is a key molecular player in the hypoxic response [22]. HIF-1 $\alpha$ is generally resided in mammal and human tissue in hypoxic condition, it has been found over-expressed in about $70 \%$ tumor [5-7]. Experiment showed that under hypoxic the transcriptive activity of HIF- $1 \alpha$ was increasing, which indicated that hypoxic microenvironment might increase the genetic transcriptional level of HIF- $1 \alpha$ to regulate the expression of downstream gene [22,23]. However, some scholars presumed hypoxic microenvironment could enhance the stability of HIF-1 $\alpha$ [24]. Our present 
A

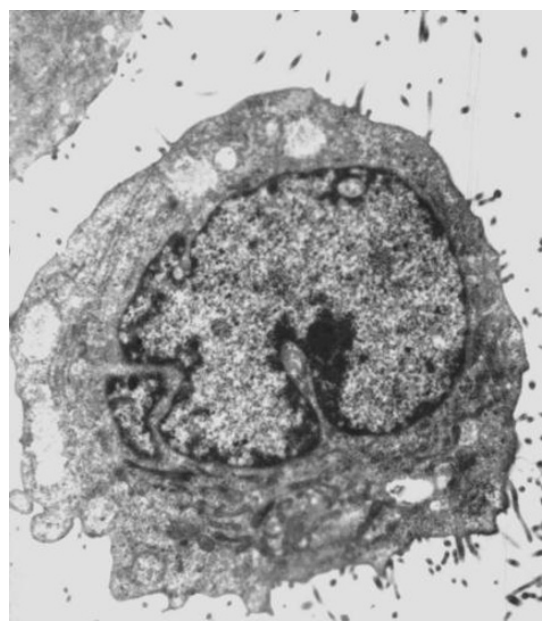

C

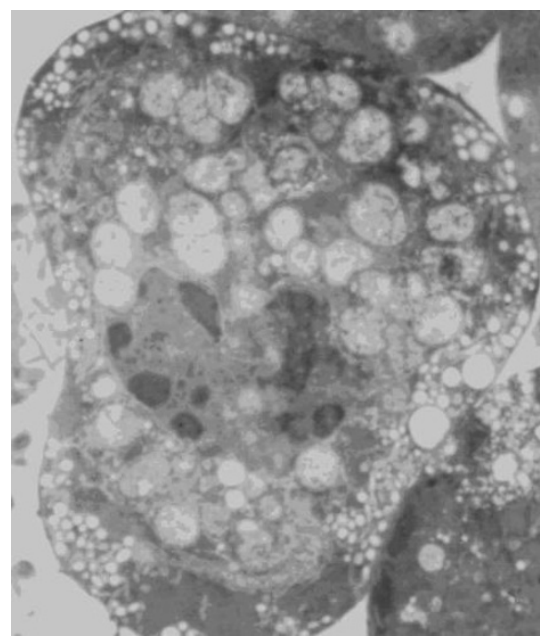

B

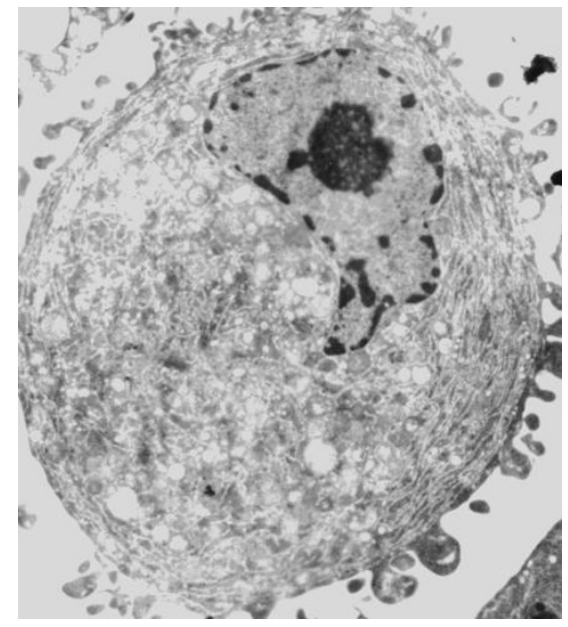

D

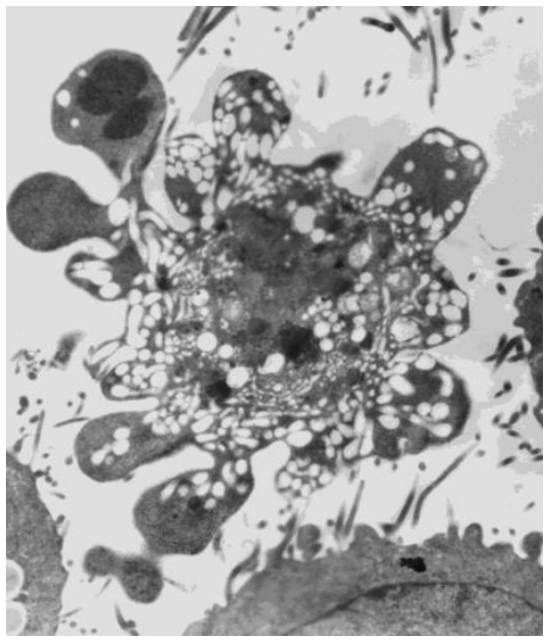

Figure 2 Morphological changes of PC-2 cells induced by hypoxia by transmission electron microscope. A: Normal pancreatic cancer PC2 cells(x6000); B: PC-2 cells in early stage of apoptosis (X6000); C: PC-2 cells in middle stage of apoptosis cell( $\times 6000)$; D: Apoptotic body $(\times 6000)$.

research indicated HIF-1 $\alpha$ obviously increased at both protein level and mRNA level in PC-2 cells under hypoxic microenvironment, and it was positive correlated with the hypoxic time and the density of $\mathrm{CoCl}_{2}$. This suggested the level of hypoxia was coinciding with the expression of HIF-1 $\alpha$.

Whether HIF- $1 \alpha$ can promote tumor cell apoptosis or anti- apoptosis, the opinion didn't reach unify, different research suggest converse results. Some date indicated overexpressed HIF- $1 \alpha$ could promote apoptosis by activating $\mathrm{Bcl}-2$ and $\mathrm{Bcl}-\mathrm{Xl}$ or enhancing the stability of p53 [25]. On the other hand, experiment displayed HIF- $1 \alpha$ could up-regulate the VEGF and GLUT1 to make tumor cell resist to apoptosis, inhibition of HIF-1 $\alpha$ could promote apoptosis [26]. In our research, under electron microscope, $\mathrm{PC}-2$ cells in hypoxic microenvironment were found in different apoptotic stage (Figure 2A-D), most were in early stage. The FCM analysis showed that the apoptotic rate of normal control group, $100 \mu \mathrm{mol} / \mathrm{L}$ group, 150 $\mu \mathrm{mol} / \mathrm{L}$ group and $200 \mu \mathrm{mol} / \mathrm{L}$ group, was $10.77 \%$, $34.32 \%, 40.17 \%$, 52.30\%, respectively. These results were consistent with Luo's research [27].

In conclusion, our study suggested that hypoxic microenvironment can effectively induce apoptosis and influence cell proliferation in PC-2 cells, and the mechanism may be concerned with the up-regulation of HIF- $1 \alpha$. 

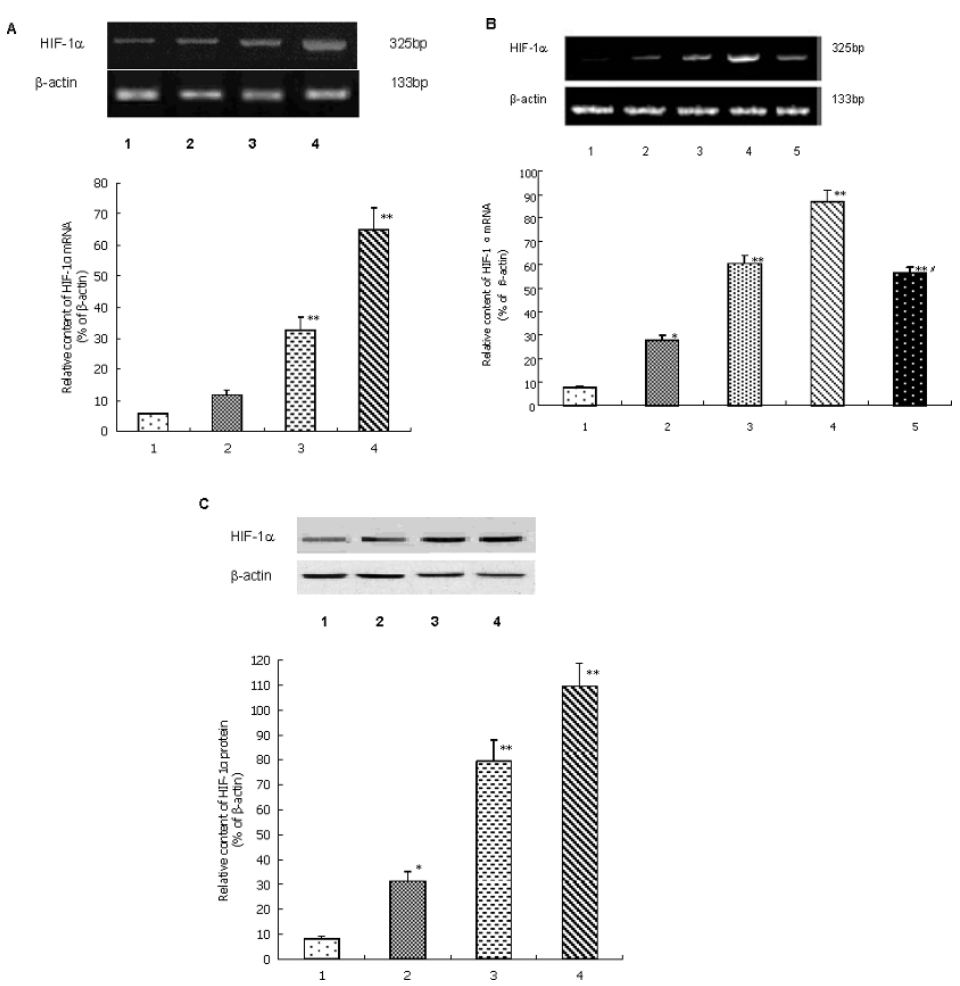

Figure 3 A: The expression of HIF-1 $\alpha$ mRNA in PC-2 cells treated with different concentration of $\mathrm{CoCl}_{2}$. 1. Normoxia group; 2 . CoCl 2 100 $\mu \mathrm{mol} / \mathrm{L}$ group; 3. $\mathrm{CoCl}_{2} 150 \mu \mathrm{mol} / \mathrm{L}$ group; 4. $\mathrm{CoCl}_{2} 200 \mu \mathrm{mol} / \mathrm{L}$ group. This assay was done quintuplicate. Values represent means \pm standard deviations $(n=5)$ and were determined using the Student's t-test. ${ }^{*} P<0.05$ and ${ }^{* *} P<0.01$ versus Normoxia group. B: The expression of HIF-1 $\alpha$ mRNA in PC-2 cells treated with $200 \mu \mathrm{mol} / \mathrm{L} \mathrm{CoCl}$ for different time. 1. 0 h; 2.4 h; 3. 8 h; 4. 12 h; 5. YC-1 2 h. This assay was done quintuplicate. Values represent means \pm standard deviations $(n=5)$ and were determined using the Student's t-test. ${ }^{*} P<0.05,{ }^{* *} P<0.01$ versus 0 h, ${ }^{\#} P<0.05$ versus 12h. C: The expression of HIF-1 $\alpha$ protein in PC-2 cells treated with different concentration of $\mathrm{CoCl}_{2}$. 1. Normoxia group; $\mathbf{2}$. CoCl 2 100 $\mu \mathrm{mol} / \mathrm{L}$ group; 3. $\mathrm{CoCl}_{2} 150 \mu \mathrm{mol} / \mathrm{L}$ group; 4 . $\mathrm{CoCl}_{2} 200 \mu \mathrm{mol} / \mathrm{L}$ group. This assay was done quintuplicate. Values represent means \pm standard deviations $(n=5)$ and were determined using the Student's $t$-test. ${ }^{*} P<0.05$ and ${ }^{* *} P<0.01$ versus Normoxia group.

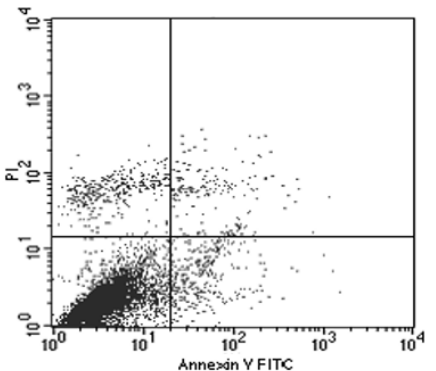

A

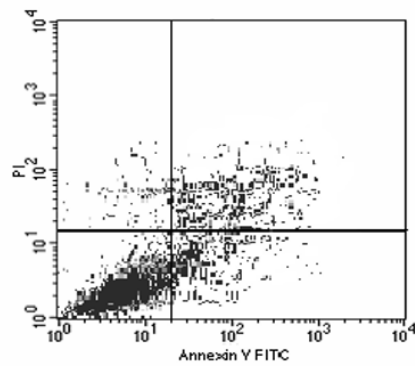

C

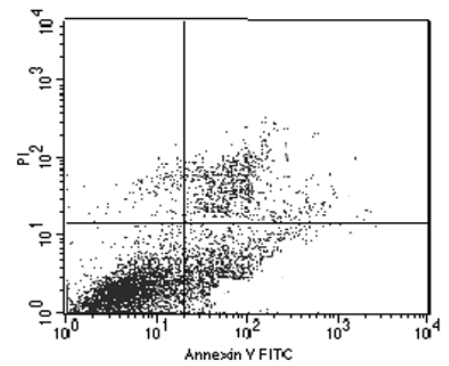

B

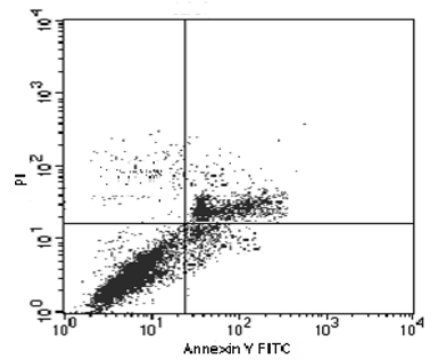

D

Figure 4 Flow cytometry was used to observe the apoptosis of PC-2 cells by staining with annexinV-FITC/PI. A. Normoxia group; B. $\mathrm{CoCl}_{2} 100 \mu \mathrm{mol} / \mathrm{L}$ group; C. CoCl $150 \mu \mathrm{mol} / \mathrm{L}$ group; D. $\mathrm{CoCl}_{2} 200 \mu \mathrm{mol} / \mathrm{L}$ group. 


\section{Conflicts of interest}

The authors declare that they have no competing interests.

\section{Acknowledgements}

This work was supported by The Science and Technology Foundation of Shaanxi Province, China, No. 2010 K01-138 and Sci-tech Program of Xi'an City, China, No. HM1117.

\section{Author details}

'Department of Oncology, the Second Affiliated Hospital, Medical School of Xi'an Jiaotong University, Xi'an, China. ${ }^{2}$ Department of Nephrology, the Second Affiliated Hospital, Medical School of Xi'an Jiaotong University, Xi'an, China. ${ }^{3}$ Department of General Surgery, the Second Affiliated Hospital, Medical School of Xi'an Jiaotong University, Xi'an, China.

\section{Authors' contributions}

DZJ and WXJ designed the research. DZJ, GJ, MXB, YK and KHF performed the experiments throughout this research. LXX, JZZ and GHT contributed to the reagents, and participated in its design and coordination. DZJ and GJ analyzed the data; DZJ and MXB wrote the paper. Co-first authors: DZJ and GJ. All authors have read and approved the final manuscript.

Received: 13 January 2012 Accepted: 27 March 2012

Published: 27 March 2012

\section{References}

1. Piret JP, Mottet $D$, Raes $M$, Michiels $C$ : $\mathrm{CoCl}_{2}$, a chemical inducer of hypoxia inducible factor-1, and hypoxia reduce apoptotic cell death in hepatoma cell line HepG2. Ann N Y Acad Sci 2002, 973(5):443-447.

2. Hockel M, Schlenger K, Aral B, Mitze M, Schaffer U, Vaupel P: Association between tumor hypoxia and malignant progression in advanced cancer of the uterine cervix. Cancer Res 1996, 56(19):4509-4515.

3. Semenza GL, Wang GL: A nuclear factor induced by hypoxia via denovoprotein synthesis binds to the human erythropoietin gene enhance ratasite required for transcriptional activation. Mol Cell Bio 1992, 12(12):5447-5456.

4. Semenza GL: Hydroxylation of HIF-1: oxygen sensing at the molecular level. Physiology 2004, 19:176-182.

5. Talks KL, Turley H, Gatter KC, Maxwell PH, Pugh CW, Ratcliffe PJ, Harris AL: The expression and distribution of the hypoxia inducible factors HIF-1 alpha and HIF-2 alpha in normal human tissues, cancers and tumorassociated macrophages. Am J Pathol 2000, 157(2):411-421.

6. Mizokami K, Kakeji Y, Oda S, Irie K, Yonemura T, Konishi F, Maehara Y: Clinicopathologic significance of hypoxia inducible factor 1alpha overexpression in gastric carcinomas. J Surg Oncol 2006, 94(2):149-154

7. Nakanishi K, Hiroi S, Tominaga S, Aida S, Kasamatsu H, Matsuyama S, Matsuyama T, Kawai T: Expression of hypoxia-inducible factor-1alpha protein predicts survival in patients with transitional cell carcinoma of the upper urinary tract. Clin Cancer Res 2005, 11(7):2583-2590.

8. Zhong H, Chiles K, Feldser D, Laughner E, Hanrahan C, Georgescu MM, Simons JW, Semenza GL: Modulation of hypoxia-inducible factor 1 a expression by the epidermal growth factor phosphatidylinositol 3kinase/PTEN/AKT/FRAP pathway in human prostate cancer cells: implications for tumor angiogenesis and therapeutics. Cancer Res 2000, 60(6):1541-1545

9. Ma L, Xie YL, Yu Y, Zhang QN: Apoptosis of human gastric cancer SGC7901 cells induced by mitomycin combined with sulindac. World J Gastroenterol 2005, 11(12):1829-1832.

10. Ma G, Yang CL, Qu Y, Wei HY, Zhang TT, Zhang NJ: The flavonoid component isorhamnetin in vitro inhibits proliferation and induces apoptosis in Eca-109 cells. Chem Biol Interact 2007, 167(2):153-160.

11. Guan HT, Xue XH, Dai ZJ, Wang XJ, Li A, Qin ZY: Downregulation of survivin expression by small interfering RNA induces pancreatic cancer cell apoptosis and enhances its radiosensitivity. World J Gastroenterol 2006, 12(18):2901-2907.

12. Bhutia SK, Mallick SK, Maiti S, Maiti TK: Antitumor and proapoptotic effect of Abrus agglutinin derived peptide in Dalton's lymphoma tumor model. Chem Biol Interact 2008, 174(1):11-18.
13. Dai ZJ, Gao J, Ji ZZ, Wang XJ, Ren HT, Liu XX, Wu WY, Kang HF, Guan HT: Matrine Induces Apoptosis in Gastric Carcinoma Cells via Alteration of Fas/FasL and Activation of Caspase-3. Journal of Ethnopharmacology 2009, 123:91-96.

14. Semenza GL: Targeting HIF-1 for cancer therapy. Nature Reviews Cancer 2003, 3:721-732.

15. Furlan D, Sahnane N, Carnevali I, Cerutti R, Uccella S, Bertolini V, Chiaravalli AM, Capella C: Up-regulation and stabilization of HIF-1a in colorectal carcinomas. Surg Oncol 2007, 16:S25-27.

16. Thomlinson $\mathrm{RH}$ : An experimental method for comparing treatments of intact malignant tumours in animals and its application to the use of oxygen in radiotherapy. Br J Cancer 1960, 14(6):555-576.

17. Azria D, Ychou M, Jacot W, Thezenas $S$, Lemanski $C$, Senesse P, Prost $P$, Delard R, Masson B, Dubois JB: Treatment of unresectable, locally advanced pancreatic adenocarcinoma with combined radiochemotherapy with 5-fluorouracil and cisplatin. Pancreas 2002, 25(4):360-365.

18. Ardyanto TD, Osaki M, Tokuyasu N, Nagahama $Y$, Ito $\mathrm{H}$ : $\mathrm{CoCl}_{2}$-induced HIF1alpha expression correlates with proliferation and apoptosis in $\mathrm{MKN}-1$ cells: a possible role for the PI3K/Akt pathway. Int J Oncol 2006, 29(3):549-555

19. Goldberg MA, Schneider TJ: Similarities between the oxygen-sensing mechanisms regulating the expression of vascular endothelial growth factor and erythropoietin. J Biol Chem 1994, 269(6):4355-4359.

20. Liu XH, Kirschenbaum A, Yao S, Stearns ME, Holland JF, Claffey K, Levine AC Upregulation of vascular endothelial factor by cobalt chloride-simulated hypoxia is mediated by persistent induction of cyclooxygenase- 2 in metastatic human prostate cancer cell line. Clin Exp Metastasis 1999, 17(8):687-694.

21. Gwak GY, Yoon JH, Kim KM, Lee HS, Chung JW, Gores GJ: Hypoxia stimulates proliferation of human hepatoma cells through the induction of hexokinase II expression. J Hepatol 2005, 42(3):358-364.

22. Covello KL, Simon MC, Keith B: Targeted replacement of hypoxiainducible factor-1 alpha by a hypoxia-inducible factor-2alpha knock-in allele promotes tumor growth. Cancer Res 2005, 65(6):2277-2286.

23. Semenza GL: HIF-1: mediator of physiological and pathophysiological responses to hypoxia. J Appl Physiol 2000, 88(4):1474-1480

24. Kallio PJ, Pongratz I, Gradin K, McGuire J, Poellinger L: Activation of hypoxia-inducible factor 1alpha: posttranscriptional regulation and conformational change by recruitment of the Arnt transcription factor. Proc Nat Acad Sci USA 1997, 94(11):5667-5672.

25. Chen DL, Li MY, Luo JY, Gu W: Direct interactions between HIF-1alpha and Mdm2 modulate p53 function. J Biol Chem 2003, 278(16):13595-13598

26. Dai S, Huang ML, Hsu CY, Chao KS: Inhibition of hypoxia inducible factor lalpha causes oxygen-independent cytotoxicity and induces p53 independent apoptosis in glioblastoma cells. Int J Radiat Oncol Bio Phys 2003, 55(4):1027-1036.

27. Luo FM, Liu XJ, Yan NH, Li SQ, Cao GQ, Cheng QY, Xia QJ, Wang HJ: Hypoxia-inducible transcription factor-1alpha promotes hypoxiainduced A549 apoptosis via a mechanism that involves the glycolysis pathway. BMC Cancer 2006, 6:26-32.

doi:10.1186/1756-9966-31-28

Cite this article as: Dai et al:: Up-regulation of hypoxia inducible factor$1 \alpha$ by cobalt chloride correlates with proliferation and apoptosis in PC2 cells. Journal of Experimental \& Clinical Cancer Research 2012 31:28. 